\title{
Genetic Diversity and Aggressiveness of Ralstonia solanacearum Strains Causing Bacterial Wilt of Potato in Uruguay
}

M. I. Siri, A. Sanabria, and M. J. Pianzzola, Cátedra de Microbiología, Departamento de Biociencias, Facultad de Química, Universidad de la República. Av. Gral. Flores 2124, CP11800, Montevideo, Uruguay

\begin{abstract}
Siri, M. I., Sanabria, A., and Pianzzola, M. J. 2011. Genetic diversity and aggressiveness of Ralstonia solanacearum strains causing bacterial wilt of potato in Uruguay. Plant Dis. 95:1292-1301.

Bacterial wilt, caused by Ralstonia solanacearum, is a major disease affecting potato (Solanum tuberosum) production worldwide. Although local reports suggest that the disease is widespread in Uruguay, characterization of prevalent $R$. solanacearum strains in that country has not been done. In all, 28 strains of $R$. solanacearum isolated from major potato-growing areas in Uruguay were evaluated, including 26 strains isolated from potato tubers and 2 from soil samples. All strains belonged to phylotype IIB, sequevar 1 (race 3 , biovar 2). Genetic diversity of strains was assessed by repetitive-sequence polymerase chain reaction, which showed that the Uruguayan strains constituted a homogeneous group. In contrast, inoculation of the strains on tomato and

potato plants showed, for the first time, different levels of aggressiveness among $R$. solanacearum strains belonging to phylotype IIB, sequevar 1. Aggressiveness assays were also performed on accessions of $S$. commersonii, a wild species native to Uruguay that is a source of resistance for potato breeding. No significant interactions were found between bacterial strains and potato and $S$. commersonii genotypes, and differences in aggressiveness among $R$. solanacearum strains were consistent with previously identified groups based on tomato and potato inoculations. Moreover, variation in responses to $R$. solanacearum was observed among the $S$. commersonii accessions tested.
\end{abstract}

Bacterial wilt, caused by the bacterium Ralstonia solanacearum, is a widespread disease affecting more than 450 plant species in tropical, subtropical, and temperate regions of the world $(14,23)$. Species belonging to the family Solanaceae are particularly susceptible, including economically important hosts such as tomato (Solanum lycopersicum), potato ( $S$. tuberosum), eggplant ( $S$. melongena), pepper (Capsicum annuum), and tobacco (Nicotiana tabacum) $(14,23,24)$. $R$. solanacearum is a soilborne pathogen that enters the plant through wounds in root tissues and progressively invades the vascular tissues, leading to partial or complete wilting and, ultimately, plant death $(10,23)$. $R$. solanacearum is a complex species with exceptional diversity among strains regarding host range, geographical distribution, pathogenicity, epidemiological relationships, and physiological properties (23). Traditionally, this complex species has been subdivided into five races on the basis of differences in host range (4) and six biovars on the basis of carbohydrate utilization (22-24). Although both classification schemes have been applied to describe strains worldwide, there are several disadvantages of each that limit their usefulness: they are time consuming, do not discriminate at a subspecific level, are not predictive of the biological properties of strains such as aggressiveness, and do not correlate well with the phylogenetic origin of bacterial strains.

Several molecular-based approaches have been developed to enhance the understanding of the genetic diversity of $R$. solanacearum. Recently, Fegan and Prior (16) proposed a new hierarchical classification scheme based on phylogenetic analysis of the internal transcribed spacer (ITS) region of ribosomal DNA and the endoglucanase gene, which proved to be more appropriate than host range and carbohydrate utilization schemes for reflecting strain

Corresponding author: M. J. Pianzzola, E-mail: mpianzzo@fq.edu.uy

GenBank accession numbers HQ198559 to HQ198584.

Accepted for publication 2 June 2011.

doi:10.1094/PDIS-09-10-0626

(c) 2011 The American Phytopathological Society diversity within the $R$. solanacearum species complex. Based on this system, four major groups, termed phylotypes, were distinguished in relation to the phylogenetic and geographic origin of strains. Phylotype I includes strains from Asia; phylotype II, strains from the Americas; phylotype III, strains from Africa and surrounding islands; and phylotype IV, strains isolated primarily from Indonesia, as well as two closely related species, $R$. syzygii and the banana blood disease bacterium (BDB). Each phylotype can be further subdivided into a variable and additive number of sequevars, which are clusters of isolates with highly conserved DNA sequences. Using this hierarchical scheme, epidemiological and ecological groups of $R$. solanacearum strains can be distinguished, thereby allowing pathologists to better predict the biological properties of unknown strains and assist in the development of effective disease management strategies compared with previous classification schemes (33).

In Uruguay, bacterial wilt caused by $R$. solanacearum is considered one of the most important diseases of potato, causing extensive damage and significant economic losses, especially when preventive control measures are not applied $(5,12)$. In addition, the disease represents a limiting factor for potato seed production systems, which have zero tolerance for this pathogen (27). The first official report of the disease in Uruguay appeared in 1974, when the impact of the disease was devastating: $59 \%$ of farmers surveyed were affected, with losses ranging from 5 to $90 \%$ of total production (5). Since then, disease incidence has been variable and characterized by the occurrence of severe outbreaks, which are difficult to prevent and control $(5,12)$. Moreover, the disease has been reported throughout the country, preventing the maintenance of pathogen-free areas for potato production $(5,12)$. In temperate to cool regions of the world, bacterial wilt of potato is mainly caused by strains belonging to phylotype II, sequevars 1 and 2 (traditionally known as race 3 , biovar 2) (24). This group of strains is very homogeneous, possesses a narrow host range, and is highly virulent on potato and tomato. Although local reports suggest that bacterial wilt is widespread in Uruguay $(5,12)$, characterization of $R$. solanacearum strains prevalent in Uruguay has not been done. A survey conducted during the 1980s determined the presence of $R$. solanacearum strains belonging to biovar 2 (6). However, this survey was not continued and, therefore, the diversity of strains that currently affect potato crops in Uruguay is unknown. 
As with many bacterial plant diseases, the most effective control strategy for $R$. solanacearum remains the use of cultivars with durable resistance (2). However, the performance of bacterial wilt resistance in potato seems relatively unstable across locations with different environmental conditions and pathogen strain diversity (2). This means that resistance breeding must be regionally targeted and breeders must screen germplasm against locally prevalent strains of $R$. solanacearum. Wild relatives of cultivated potato provide a rich, unique, and diverse source of genetic variation for potato breeding (3). Extensive efforts have been made to transfer bacterial wilt resistance from various wild potato relatives. Disappointingly, sexual hybrids of potato with $S$. chacoense, $S$. sparsipillum, and $S$. multidissectum accessions achieved only a moderate level of resistance, as well as some undesirable wild traits, such as high glycoalkaloid content $(2,19)$. A valuable genetic resource available for potato breeding in Uruguay is the wild species $S$. commersonii Dun (21). This tuber-bearing species native to Uruguay carries many desirable traits, such as tolerance to low temperatures and resistance to several pathogens $(8,50)$. Some studies have reported the use of $S$. commersonii as a source of resistance to bacterial wilt $(7,32)$. However, little is known about resistance across the spectrum of diversity in this wild plant species, or about pathogenic fitness of different $R$. solanacearum strains on this plant species. In a previous study, we evaluated a collection of $S$. commersonii accessions from different areas across Uruguay (46). Wide genetic variation in bacterial wilt resistance was observed. Those findings highlight the potential of this species as a valuable genetic resource for Uruguayan and other potato-breeding programs.

Knowledge of local pathogen populations is a key factor for successful breeding and integrated pest management programs. One objective of this study was to characterize $R$. solanacearum strains collected in Uruguay with respect to biovar, phylotype, sequevar, and genetic diversity. Another objective was to analyze phenotypic variation of strains of the pathogen by performing a comparative aggressiveness analysis on different hosts, including tomato, potato, and $S$. commersonii accessions, differing in resistance to $R$. solanacearum. The information generated in this study is expected to lead to improved management strategies for this important disease in Uruguay.

\section{Materials and Methods}

Bacterial strains, isolation, and growth conditions. Bacterial strains used in this study are listed in Table $1 . R$. solanacearum strains were isolated from potato tubers and soil samples collected from fields in the main areas of potato production in Uruguay from 2003 to 2009. Naturally infected potato plants showing bacterial wilt symptoms were provided by potato growers from diverse locations in Uruguay for disease diagnosis. From each field, 5 to 10 tubers with typical brown rot symptoms (creamy exudates from the vascular rings and eyes of tubers) were used for isolation of $R$. solanacearum. Potato tubers were washed thoroughly with water; and surface sterilized with $70 \%$ ethanol, and a transverse section was made with a sterile scalpel. After pressing the tuber, a sterile loop was used to sample vascular exudates and streaked directly onto modified SMSA medium (mSMSA) (15). Soil samples were collected from six fields distributed among potato-growing areas in Uruguay (two fields per region: San José, Rocha, and Tacuarembó). Each field was sampled at 25 points following a zigzag pattern. Three subsamples were collected at each sampling point, combined, and homogenized manually to form a composite sample of 200 to $500 \mathrm{~g}$ soil. Soil from each composite sample ( $2 \mathrm{~g}$ ) was incubated for $48 \mathrm{~h}$ in liquid mSMSA to enrich $R$. solanacearum cells. A loopful of liquid bacterial culture was then streaked on modified mSMSA agar for isolation of single colonies. Plates were incubated for 3 to 5 days at $28^{\circ} \mathrm{C}$. Colonies with typical $R$. solanacearum phenotype (irregular shaped, fluidal, and entirely white or with a pink center) were subcultured onto tetrazolium chloride agar (TZC) medium (30) and purified for further study.

Additionally, 11 unknown $R$. solanacearum strains were kindly provided by the governmental Plant Protection Service in Uruguay
(E. Verdier, Montevideo, Uruguay). These strains were isolated from potato tubers during a severe outbreak of bacterial wilt in the 1980 s and were identified as $R$. solanacearum race 3, biovar 2 (6; Table 1). Reference strains IPO1609 and UW551 were kindly provided by C. Boucher (LIPM-INRA, Toulouse, France) and included as control treatments for genetic and pathogenic characterization of the Uruguayan strains of $R$. solanacearum (Table 1).

Identification and long-term storage of bacterial strains. For each strain, a single, well-isolated colony was selected and subjected to colony polymerase chain reaction (PCR) using primers OL1 1-Y2 (43). A loopful of each colony was resuspended in $50 \mu l$ of sterile distilled water, boiled for $20 \mathrm{~min}$, cooled on ice for $3 \mathrm{~min}$, and centrifuged at $6,000 \mathrm{rpm}$ for $1 \mathrm{~min}$. PCR amplification was performed in a total volume of $25 \mu \mathrm{l}$ containing $5 \mu \mathrm{l}$ of boiled supernatant, $1 \times$ DNA polymerase buffer, $1.5 \mathrm{mM} \mathrm{MgCl}_{2}, 0.5 \mu \mathrm{M}$ each primer, $200 \mu \mathrm{M}$ each dNTP, and 1U Taq DNA polymerase (Invitrogen Life Technologies, Sao Paulo, Brazil). Amplification was performed in a Gradient Palm Cycler (Qiagen, Valencia, CA), with an initial denaturation step at $95^{\circ} \mathrm{C}$ for $2 \mathrm{~min}$; followed by 35 cycles of denaturation at $94^{\circ} \mathrm{C}$ for $20 \mathrm{~s}$, annealing at $68^{\circ} \mathrm{C}$ for $20 \mathrm{~s}$, and extension at $72^{\circ} \mathrm{C}$ for $30 \mathrm{~s}$; and a final extension step at $72^{\circ} \mathrm{C}$ for $5 \mathrm{~min}$. PCR products $(8 \mu \mathrm{l})$ were analyzed by electrophoresis through $1 \%(\mathrm{wt} / \mathrm{vol})$ agarose gels with ethidium bromide at 0.5 $\mu \mathrm{g} / \mathrm{ml}$, and photographed under UV light.

All PCR-positive bacterial strains were then confirmed by pathogenicity tests on potato. Plantlets were micropropagated from single-node pieces growing in vitro on Murashige and Skoog agar medium (38) supplemented with sucrose at $30 \mathrm{~g} / \mathrm{liter}$, and maintained at $22^{\circ} \mathrm{C}$ with $16 \mathrm{~h}$ of light and $8 \mathrm{~h}$ of darkness per day. After 3 weeks, plantlets were transferred into plastic flats with $17-\mathrm{cm}^{3}$ cells containing commercial soil mix (TREF, Moerdijk, The Netherlands) and placed in a greenhouse at 22 to $25^{\circ} \mathrm{C}$ under natural light for acclimatization 2 weeks prior to inoculation. Four plants were inoculated with each $R$. solanacearum strain by direct stem inoculation, as previously described (46). Plants inoculated with saline solution were used as negative control treatments. Inoculated plants were held in a growth chamber at $28^{\circ} \mathrm{C}$ with a 12-h photoperiod per day. Reisolation of bacteria onto mSMSA agar medium was performed from the vascular tissue of inoculated and noninoculated control plants. All $R$. solanacearum strains were stored at $-70^{\circ} \mathrm{C}$ in casamino acid peptone glucose (CPG) broth (25) with $18 \%$ glycerol. Individual isolates were also maintained as suspensions in sterile distilled water at room temperature.

Biovar determination. Uruguayan strains of $R$. solanacearum were classified to biovar using the physiological tests developed by Hayward (22), which assess the ability of strains to oxidize a panel of sugars and sugar alcohols. Freshly cultured $R$. solanacearum cells were stabbed into a soft agar tube of Hayward's agar medium containing $1 \%(\mathrm{wt} / \mathrm{vol})$ filter-sterilized lactose, maltose, cellobiose, manitol, sorbitol, or dulcitol, and incubated at $28^{\circ} \mathrm{C}$ for 14 days. Each test was carried out twice and noninoculated tubes were used as negative control treatments in each repeat of the tests. The color change of the tubes was recorded daily. Acid production changed the color of the culture medium from green to yellow (22).

DNA extraction. Bacterial growth from a single, well-isolated colony of each strain of $R$. solanacearum on TZC agar medium was used to inoculate $5 \mathrm{ml}$ of liquid $\mathrm{CPG}$. The culture was grown at $28^{\circ} \mathrm{C}$ for $48 \mathrm{~h}$ with shaking at $200 \mathrm{rpm}$. The entire bacterial suspension was then pelleted by centrifugation and total genomic DNA was extracted using standard procedures (1). Quality and quantity of DNA preparations were checked by gel electrophoresis and standard spectrophotometry by measuring absorbance at 260 and $280 \mathrm{~nm}$ (1). DNA samples were stored at $-20^{\circ} \mathrm{C}$.

Phylotype identification. Phylotype affiliation of the Uruguayan strains of $R$. solanacearum was determined by multiplex PCR using a set of phylotype-specific primers (Nmult:21:1F, Nmult:21:2F, Nmult:22:InF, Nmult:23:AF, and Nmult21:RR) and species-specific primers (759/760) (16). Amplification was carried out in a total volume of $25 \mu \mathrm{l}$ containing $1 \times$ DNA polymerase buffer, $1.5 \mathrm{mM} \mathrm{MgCl} 2,200 \mu \mathrm{M}$ each dNTP, 6 pmol each phylo- 
type-specific primer, 4 pmol species-specific primers, $2 \mathrm{U}$ of Taq DNA polymerase, and $50 \mathrm{ng}$ of DNA template. Amplifications were performed in an automated Corbett thermocycler with an initial denaturation step at $96^{\circ} \mathrm{C}$ for $5 \mathrm{~min}$; followed by 30 cycles of denaturation at $94^{\circ} \mathrm{C}$ for $15 \mathrm{~s}$, annealing at $59^{\circ} \mathrm{C}$ for $30 \mathrm{~s}$, and extension at $72^{\circ} \mathrm{C}$ for $30 \mathrm{~s}$; with a final extension step at $72^{\circ} \mathrm{C}$ for $10 \mathrm{~min}$. PCR products $(12 \mu \mathrm{l})$ were analyzed by electrophoresis through $2 \%(\mathrm{wt} / \mathrm{vol})$ agarose gels with ethidium bromide at 0.5 $\mu \mathrm{g} / \mathrm{ml}$ and photographed under UV light.

PCR amplification and sequencing of the endoglucanase gene. PCR amplification of a 750-bp fragment of the endoglucanase $(e g l)$ gene was performed for each of the $R$. solanaceaum strains using the primer pair Endo-F and Endo-R (17). Amplification was carried out in a total volume of $25 \mu$ containing $1 \times$ DNA polymerase buffer, $1.5 \mathrm{mM} \mathrm{MgCl} 2,200 \mu \mathrm{M}$ each dNTP, $10 \mathrm{pmol}$ each primer, $1 \mathrm{U}$ of Taq DNA polymerase, and $50 \mathrm{ng}$ of DNA template. Amplifications were performed in an automated Corbett thermocycler with an initial denaturation step at $96^{\circ} \mathrm{C}$ for $9 \mathrm{~min}$; followed by 30 cycles of denaturation at $95^{\circ} \mathrm{C}$ for $1 \mathrm{~min}$, annealing at $70^{\circ} \mathrm{C}$ for $1 \mathrm{~min}$, and extension at $72^{\circ} \mathrm{C}$ for $2 \mathrm{~min}$; with a final extension step at $72^{\circ} \mathrm{C}$ for $10 \mathrm{~min}$. PCR products were purified and sequenced by Macrogen Services (Kumchun-ku, Seoul, Korea) using Endo-F and Endo-R primers. Sequences were edited and assembled with Vector NTI Advance 11.0 sequence analysis software (Invitrogen) and deposited in the GenBank database. Phylogenetic analysis was performed with MEGA 3.0 (31) by using neighbor-joining and the algorithm of Jukes and Cantor (29) with 1,000 bootstraps resamplings. The following 28 reference sequences were retrieved from GenBank and included in the phylogenetic analysis in order to include a wide range of the genetic diversity of the $R$. solanacearum species complex: R292 (AF295255), NCPPB3190 (AF295253), GMI1000 (DQ657595), U154 (AY464996), MOD5 (AY464992), UW21 (DQ011546), UW469 (AF295269), UW477 (DQ657604), CFBP2958 (AF295266), CFBP2957 (EF371807), UW167 (DQ011545), UW276 (DQ657610), UW344 (DQ657620), UW551 (DQ657596), CFBP3858 (AF295259), JT516 (EF647737), CFBP3059 (DQ657647), J25 (AF295279), JT525 (AF295272), JT528

Table 1. Ralstonia solanacearum strains used in this study

\begin{tabular}{|c|c|c|c|c|c|}
\hline \multirow[b]{2}{*}{ Strain } & \multicolumn{2}{|c|}{ Origin } & \multirow[b]{2}{*}{ Sample } & \multirow[b]{2}{*}{ Biovarw $^{w}$} & \multirow[b]{2}{*}{ Phylotype/sequevar $^{\mathrm{x}}$} \\
\hline & Year & Location $^{v}$ & & & \\
\hline \multicolumn{6}{|c|}{ Uruguayan strains } \\
\hline UY031 & 2003 & San José & Potato tuber & 2 & II/1 \\
\hline UY032 & 2003 & San José & Potato tuber & 2 & II/1 \\
\hline UY033 & 2003 & Tacuarembó & Potato tuber & 2 & $\mathrm{II} / 1$ \\
\hline UY034 & 2003 & Tacuarembó & Potato tuber & 2 & $\mathrm{II} / 1$ \\
\hline UY035 & 2003 & Tacuarembó & Potato tuber & 2 & $\mathrm{II} / 1$ \\
\hline UY036 & 2003 & Tacuarembó & Potato tuber & 2 & II/1 \\
\hline UY041 & 2004 & Rocha & Potato tuber & 2 & $\mathrm{II} / 1$ \\
\hline UY042 & 2004 & Rocha & Potato tuber & 2 & $\mathrm{II} / 1$ \\
\hline UY043 & 2004 & Tacuarembó & Soil & 2 & II/1 \\
\hline UY071 & 2007 & Rocha & Soil & 2 & $\mathrm{II} / \mathrm{nd}$ \\
\hline UY072 & 2007 & Tacuarembó & Potato tuber & 2 & II/1 \\
\hline UY081 & 2008 & San José & Potato tuber & 2 & II/1 \\
\hline UY082 & 2008 & San José & Potato tuber & 2 & II/1 \\
\hline UY083 & 2008 & San José & Potato tuber & 2 & II/1 \\
\hline UY084 & 2008 & San José & Potato tuber & 2 & $\mathrm{II} / 1$ \\
\hline UY085 & 2008 & San José & Potato tuber & 2 & II/1 \\
\hline UY086 & 2008 & Rocha & Potato tuber & 2 & II/1 \\
\hline UY087 & 2008 & Rocha & Potato tuber & 2 & $\mathrm{II} / 1$ \\
\hline UY088 & 2008 & Rocha & Potato tuber & 2 & II/1 \\
\hline UY089 & 2008 & Rocha & Potato tuber & 2 & II $/ 1$ \\
\hline UY0810 & 2008 & Rocha & Potato tuber & 2 & II/1 \\
\hline UY091 & 2009 & San José & Potato tuber & 2 & II/1 \\
\hline UY092 & 2009 & San José & Potato tuber & 2 & $\mathrm{II} / \mathrm{nd}$ \\
\hline UY093 & 2009 & San José & Potato tuber & 2 & $\mathrm{II} / \mathrm{nd}$ \\
\hline UY094 & 2009 & San José & Potato tuber & 2 & $\mathrm{II} / \mathrm{nd}$ \\
\hline UY095 & 2009 & Rocha & Potato tuber & 2 & II/nd \\
\hline UY096 & 2009 & Rocha & Potato tuber & 2 & II/nd \\
\hline UY097 & 2009 & Rocha & Potato tuber & 2 & $\mathrm{II} / \mathrm{nd}$ \\
\hline DGSA114 & 1980-1984 & San José & Potato tuber & 2 & II/1 \\
\hline DGSA115y & 1980-1984 & San José & Potato tuber & 2 & $\mathrm{II} / 1$ \\
\hline DGSA116y & 1980-1984 & San José & Potato tuber & 2 & $\mathrm{II} / 1$ \\
\hline DGSA117y & 1980-1984 & San José & Potato tuber & 2 & $\mathrm{II} / 1$ \\
\hline DGSA119y & 1980-1984 & San José & Potato tuber & 2 & $\mathrm{II} / 1$ \\
\hline DGSA120y & 1980-1984 & San José & Potato tuber & 2 & $\mathrm{II} / 1$ \\
\hline DGSA127y & 1980-1984 & San José & Potato tuber & 2 & $\mathrm{II} / 1$ \\
\hline DGSA130y & 1980-1984 & San José & Potato tuber & 2 & $\mathrm{II} / 1$ \\
\hline DGSA132y & 1980-1984 & Tacuarembó & Potato tuber & 2 & II/1 \\
\hline DGSA133y & 1980-1984 & Tacuarembó & Potato tuber & 2 & II/1 \\
\hline DGSA135y & 1980-1984 & San José & Potato tuber & 2 & II/1 \\
\hline \multicolumn{6}{|c|}{ Reference strains ${ }^{\mathrm{z}}$} \\
\hline IPO1609 & 1995 & The Netherlands & Potato tuber & 2 & $\mathrm{II} / 1$ \\
\hline UW551 & 2003 & Kenya & Geranium & 2 & $\mathrm{II} / 1$ \\
\hline
\end{tabular}

v Strains were collected from three potato-growing areas in Uruguay: San José (south), Tacuarembó (north), and Rocha (east). Strains came from different fields that had previously been planted to potato production, with the exception of strains UY031 and UY032 that were isolated from different potato tubers collected in the same field.

${ }^{\mathrm{w}}$ Biovar was determined for each strain as described in the main text, or provided by the suppliers of the strains.

x Abbreviation: $\mathrm{nd}=$ not determined.

y Strains isolated during the 1980s and maintained at the Plant Protection Service, Montevideo, Uruguay.

${ }^{\mathrm{z}}$ Reference strains IPO1609 and UW551 were kindly provided by C. Boucher (LIPM- INRA, Toulouse, France). 
(AF295273), NCPPB283 (AF295275), NCPPB332 (DQ657649), NCPPB505 (AF295277), NCPPB1018 (AF295271), ICMP9915 (DQ011555), MAFF301558 (AY465002), R28 (DQ011552), R230 (AF295280), and R233 (DQ011542).

Repetitive-sequence PCR assay. Genetic diversity of the Uruguayan $R$. solanacearum strains was determined by repetitive (rep)-PCR assay employing the BOXAIR primer (5'-CTACGGCAAGGCGACGCTGACG-3') (35). Reference potato strains UW551 and IPO1609 were included in the analysis. Genomic DNA from $R$. solanacearum strain GMI1000, kindly provided by C. Boucher (LIPM-INRA), was used as an outgroup for the genetic analysis. PCR amplifications were performed in $25-\mu 1$ reaction volumes containing $1 \times$ DNA polymerase buffer, $6.8 \mathrm{mM} \mathrm{MgCl}_{2}$, $200 \mu \mathrm{M}$ each dNTP, 50 pmol primer, $2 \mathrm{U}$ of Taq DNA polymerase, and $50 \mathrm{ng}$ of DNA template. Amplifications were performed in an automated Corbett thermocycler with an initial denaturation step at $95^{\circ} \mathrm{C}$ for $7 \mathrm{~min}$; followed by 30 cycles of denaturation at $94^{\circ} \mathrm{C}$ for $1 \mathrm{~min}$, annealing at $53^{\circ} \mathrm{C}$ for $1 \mathrm{~min}$, and extension at $65^{\circ} \mathrm{C}$ for 8 min; and a final extension step at $65^{\circ} \mathrm{C}$ for $16 \mathrm{~min}$. To confirm reproducibility of the results, amplifications were repeated twice for each bacterial strain. PCR products $(12 \mu \mathrm{l})$ were analyzed by electrophoresis through $2 \%(\mathrm{wt} / \mathrm{vol})$ agarose gels with ethidium bromide at $0.5 \mu \mathrm{g} / \mathrm{ml}$ and photographed under UV light. Gel images were analyzed with the software Gel Compar 4.2 (Kortrijk, Belgium). Differences in banding patterns observed were established by the presence or absence (indicated by 1 or 0 , respectively) of an amplification product. The percent reproducibility of the banding patterns was determined by dividing the number of reproducible bands by the total number of bands observed. Nonreproducible bands were not used for the analysis. A similarity matrix was constructed from the binary data with Dice's coefficients (11), and a dendrogram was generated with the unweighted pairgroup method using arithmetic averages clustering algorithm. The goodness of fit of the cluster analysis to the associated similarity matrix was computed by co-phenetic correlation analysis (48).

Bacterial aggressiveness assays. Aggressiveness of a subset of $R$. solanacearum strains was determined on tomato ('Loica'), po- tato ('Chieftain'), and three accessions of the wild potato relative, S. commersonii ( $\mathrm{Sc} 1, \mathrm{Sc} 19$, and $\mathrm{Sc} 26$ ). To prepare inocula, bacterial strains were grown overnight in liquid $\mathrm{CPG}$ at $28^{\circ} \mathrm{C}$ with shaking at $200 \mathrm{rpm}$. Cells were pelleted by centrifugation, suspended in $0.9 \%$ saline solution, and spectrophotometrically adjusted to $10^{8}$ $\mathrm{CFU} / \mathrm{ml}$ (optical density at $600 \mathrm{~nm}$ of 0.1 ). Inoculum concentration was confirmed by dilution plating on TZC agar medium. In all, 11 and 16 Uruguayan $R$. solanacearum strains isolated from 2003 to 2009 from potato-production regions of Uruguay (Table 1) were assayed for aggressiveness on tomato and potato, respectively (Table 2). Different numbers of bacterial strains were tested on both host species due to space limitation in the growth chamber. Reference strains IPO1609 and UW551 were included as control treatments. In addition, 13 and 9 Uruguayan $R$. solanacearum strains were assayed for aggressiveness on $S$. commersonii in two independent experiments (Table 3 ).

Tomato seedlings were grown from seed in plastic flats with 12 cells (each $17 \mathrm{~cm}^{3}$ ) containing commercial TREF soil mix. Plants were grown in a greenhouse at 22 to $25^{\circ} \mathrm{C}$ under natural light for 3 weeks prior to inoculation. Potato plants were micropropagated from single-node pieces growing in vitro on Murashige and Skoog agar medium supplemented with sucrose at $30 \mathrm{~g} / \mathrm{liter}$ and maintained at $22^{\circ} \mathrm{C}$ with a cycle of $16 \mathrm{~h}$ of light and $8 \mathrm{~h}$ of darkness. After 3 weeks, potato plantlets were transferred into plastic flats with 10 cells (each $17 \mathrm{~cm}^{3}$ ) containing TREF soil mix and placed in a greenhouse at 22 to $25^{\circ} \mathrm{C}$ under natural light for 2 weeks for acclimatization prior to inoculation. Tomato and potato plants with six to eight fully expanded leaves (approximately $10-\mathrm{cm}$-tall plants) were tested in separate experiments by soil inoculation (36). Prior to inoculation, roots were slightly damaged by making a hole into the soil next to each plant with a disposable pipette tip ( 2 $\mathrm{cm}$ deep). Inoculation was performed by pouring $1 \mathrm{ml}$ of the appropriate bacterial suspension into each hole $\left(5 \times 10^{6} \mathrm{CFU} / \mathrm{g}\right.$ soil). A set of 12 tomato plants and 10 potato plants was inoculated with each strain. Each flat was placed on a separate tray to prevent cross-contamination among bacterial strains. Plants in three replicate trays were inoculated with each strain or with saline solution

Table 2. Aggressiveness of Ralstonia solanacearum strains on tomato (Solanum lycopersicum 'Loica') and potato (S. tuberosum 'Chieftain')

\begin{tabular}{|c|c|c|c|c|}
\hline \multirow[b]{3}{*}{ Strain } & \multicolumn{4}{|c|}{ Aggressiveness on $^{x}$} \\
\hline & \multicolumn{2}{|c|}{ Tomato } & \multicolumn{2}{|c|}{ Potato } \\
\hline & AUDPCy & Wilting $(\%)^{\mathrm{z}}$ & AUDPC $^{y}$ & Wilting $(\%)^{\mathrm{z}}$ \\
\hline UW551 & $48.3 \mathrm{~A}$ & $98.3 \mathrm{~A}$ & $45.2 \mathrm{~A}$ & $98.3 \mathrm{~A}$ \\
\hline UY031 & $46.8 \mathrm{~A}$ & $98.3 \mathrm{~A}$ & $43.9 \mathrm{~A}$ & $96.7 \mathrm{~A}$ \\
\hline UY032 & $39.3 \mathrm{~A}$ & $90.3 \mathrm{~A}$ & $42.3 \mathrm{~A}$ & $96.7 \mathrm{~A}$ \\
\hline UY085 & nd & nd & $41.2 \mathrm{~A}$ & $96.7 \mathrm{~A}$ \\
\hline UY036 & $38.8 \mathrm{~A}$ & $88.6 \mathrm{~A}$ & $41.8 \mathrm{~A}$ & $95.0 \mathrm{~A}$ \\
\hline UY084 & nd & nd & $39.1 \mathrm{~A}$ & $95.0 \mathrm{~A}$ \\
\hline UY041 & $45.6 \mathrm{~A}$ & $98.3 \mathrm{~A}$ & $40.6 \mathrm{~A}$ & $93.3 \mathrm{~A}$ \\
\hline UY042 & $45.0 \mathrm{~A}$ & $97.2 \mathrm{~A}$ & $40.7 \mathrm{~A}$ & $93.3 \mathrm{~A}$ \\
\hline UY082 & nd & nd & $40.7 \mathrm{~A}$ & $93.3 \mathrm{~A}$ \\
\hline UY087 & nd & nd & $39.5 \mathrm{~A}$ & $93.3 \mathrm{~A}$ \\
\hline UY091 & nd & nd & $38.3 \mathrm{~A}$ & $93.3 \mathrm{~A}$ \\
\hline UY034 & $41.3 \mathrm{~A}$ & $92.2 \mathrm{~A}$ & $42.2 \mathrm{~A}$ & $91.7 \mathrm{~A}$ \\
\hline UY092 & nd & nd & $38.0 \mathrm{~A}$ & $90.0 \mathrm{~A}$ \\
\hline UY089 & nd & nd & $37.2 \mathrm{~A}$ & $90.0 \mathrm{~A}$ \\
\hline UY072 & $44.9 \mathrm{~A}$ & $96.5 \mathrm{~A}$ & nd & nd \\
\hline IPO1609 & $22.4 \mathrm{~B}$ & $52.4 \mathrm{~B}$ & $23.3 \mathrm{AB}$ & $59.2 \mathrm{AB}$ \\
\hline UY071 & $14.4 \mathrm{~B}$ & $47.6 \mathrm{~B}$ & $10.4 \mathrm{~B}$ & $35.0 \mathrm{~B}$ \\
\hline UY035 & $147.4 \mathrm{~B}$ & $52.2 \mathrm{~B}$ & $10.2 \mathrm{~B}$ & $25.0 \mathrm{~B}$ \\
\hline UY033 & $18.6 \mathrm{~B}$ & $52.4 \mathrm{~B}$ & $8.9 \mathrm{~B}$ & $25.0 \mathrm{~B}$ \\
\hline UY043 & $12.1 \mathrm{~B}$ & $38.9 \mathrm{~B}$ & $7.0 \mathrm{~B}$ & $23.3 \mathrm{~B}$ \\
\hline
\end{tabular}

${ }^{\mathrm{x}}$ Refer to the main text for details on the inoculation protocol. Tomato and potato plants inoculated with saline solution (negative control treatments) remained healthy in all experiments.

y AUDPC $=$ area under the disease progress curve based on the average wilting rating. Values are means of two repeated trials of each experiment. Data were pooled across trials since no significant effects involving trials were found in the analyses of variance (ANOVAs). Values followed by the same letter in the same column are not significantly different (Tukey's multiple comparison test, $P=0.05$ ).

${ }^{\mathrm{z}}$ Mean percentage of wilted plants assessed 21 days after inoculation. Values are means of two repeated trials of each experiment. Data were pooled across trials because no significant effects involving trials were found in the ANOVAs. Values followed by the same letter in the same column are not significantly different (Tukey's multiple comparison test, $P=0.05$ ); nd = not determined. 
(negative control treatment) in a completely randomized design, and each experiment was repeated once under the same experimental conditions, for a total of two trials for each host. After inoculation, plants were incubated in a growth chamber at $28^{\circ} \mathrm{C}$ with a 12 $\mathrm{h}$ photoperiod.

Disease development was recorded at 4-day intervals using an ordinal scale ranging from 0 (no wilting symptoms) to 4 (all leaves wilted) for up to 21 days after inoculation (54). Strain aggressiveness was estimated by the area under disease progression curve (AUDPC) based on the average wilt scoring for each combination of strain and host (44). Disease incidence was evaluated 21 days after inoculation as the percentage of plants wilting. AUDPC and incidence data from trials of experiments performed on the same host were combined, and analysis of variance (ANOVA) was conducted to identify significant effects of trials, strains, and interactions between the main effects of trials and strains. Means were pooled across trials when no significant effects involving trials were found. When a significant strain main effect was found in the ANOVAs, means were compared according to Tukey's multiple comparison procedure using INFOSTAT (13). Scheffe's contrasts were calculated to compare the means for groups of strains with different geographic origin (37).

A subset of $R$. solanacearum strains was evaluated for aggressiveness on three $S$. commersonii accessions obtained from a germplasm collection maintained at the National Institute for Agricultural Research (INIA, Las Brujas, Uruguay). Thirteen strains were tested in the first experiment and a subset of nine of these strains was tested in a repeat experiment (Table 3). Three $S$. commersonii genotypes (accession names Sc1, Sc19, and Sc26) carrying different levels of genetic resistance to bacterial wilt were selected based on a previous screening (46). Chieftain potato plants were included as a susceptible control treatment. $S$. commersonii accessions were propagated in vitro as described above for potato plants, with the exception that 4 to 5 weeks were required for rooting prior to transplanting. Plants with six to eight fully expanded leaves were infected by soil inoculation. Preparation of inocula, the inoculation procedure, and incubation conditions were the same as described above. In all, 10 plants of each accession (= 10 replicates) were inoculated with each strain or with saline solution (negative control treatment) in a randomized complete block design with two blocks (replicates). Disease development was recorded at 4-day intervals for 21 days, and AUDPC was calculated for each combination of strain and host based on the average wilting score (44). ANOVA was used to determine the effects of strain, host, and strain-host interactions on the AUDPC. Means were compared using Tukey's multiple comparison test using INFOSTAT (13). Data from both experiments were analyzed separately because of the different number of $R$. solanacearum strains evaluated in each trial.

\section{Results}

Strain isolation, identification, and characterization. In total, 28 bacterial strains were collected from fields located in the main potato production regions of Uruguay during the period 2003 to 2009 , including 26 strains isolated from potato tubers and 2 strains isolated from soil samples (Table 1). All strains were confirmed as $R$. solanacearum by colony PCR, yielding an expected 280-bp fragment following amplification with primers OLI1-Y2 (data not shown). Furthermore, all strains isolated produced typical symptoms of wilting on potato plants 4 to 5 days after direct stem inoculation (data not shown). The strains were reisolated from the stem vascular tissues of wilting potato plants and showed typical colony phenotype on TZC agar medium. In contrast, the 11 archival strains isolated during the 1980s did not cause wilt symptoms on potato, and no bacteria were reisolated from asymptomatic plants

Table 3. Aggressiveness of Ralstonia solanacearum strains from Uruguay inoculated on potato plants (Solanum tuberosum 'Chieftain') as well as $S$. commersonii accessions originating from Uruguayw

\begin{tabular}{|c|c|c|c|c|c|}
\hline \multirow[b]{3}{*}{ Strain } & \multicolumn{4}{|c|}{ Aggressiveness (AUDPC) $^{x}$} & \multirow[b]{3}{*}{$\operatorname{Mean}^{\mathrm{z}}$} \\
\hline & \multirow[b]{2}{*}{ S. tuberosum ${ }^{\mathrm{y}}$} & \multicolumn{3}{|c|}{ S. commersonii accessions } & \\
\hline & & Sc26 & Sc19 & Sc1 & \\
\hline \multicolumn{6}{|c|}{ Experiment 1} \\
\hline UY031 & 47.2 & 40.8 & 23.6 & 5.3 & $29.2 \mathrm{~A}$ \\
\hline UY041 & 47.1 & 43.0 & 22.2 & 3.9 & $29.0 \mathrm{~A}$ \\
\hline UY091 & 39.0 & 42.2 & 21.7 & 5.3 & $27.0 \mathrm{~A}$ \\
\hline UY042 & 40.5 & 42.0 & 21.4 & 3.5 & $26.8 \mathrm{~A}$ \\
\hline UY082 & 41.9 & 41.4 & 19.0 & 3.6 & $26.5 \mathrm{~A}$ \\
\hline UY036 & 39.4 & 40.8 & 17.4 & 7.6 & $26.3 \mathrm{~A}$ \\
\hline UY072 & 40.2 & 39.6 & 22.3 & 3.3 & $26.3 \mathrm{~A}$ \\
\hline UY032 & 41.4 & 37.5 & 20.4 & 5.6 & $26.2 \mathrm{~A}$ \\
\hline UY087 & 40.0 & 36.0 & 17.7 & 8.3 & $25.5 \mathrm{~A}$ \\
\hline UY084 & 35.8 & 41.7 & 22.8 & 1.4 & $25.4 \mathrm{~A}$ \\
\hline UY071 & 22.8 & 23.4 & 4.8 & 0.0 & $12.7 \mathrm{~B}$ \\
\hline UY033 & 21.1 & 21.2 & 2.7 & 0.0 & $11.2 \mathrm{~B}$ \\
\hline UY043 & 10.8 & 11.8 & 0.9 & 0.0 & $5.9 \mathrm{~B}$ \\
\hline Mean $^{z}$ & $35.9 \mathrm{~A}$ & $35.5 \mathrm{~A}$ & $16.7 \mathrm{~B}$ & $3.7 \mathrm{C}$ & $\ldots$ \\
\hline \multicolumn{6}{|c|}{ Experiment 2} \\
\hline UY041 & 43.7 & 39.6 & 20.0 & 7.8 & $27.8 \mathrm{~A}$ \\
\hline UY031 & 44.0 & 38.8 & 19.9 & 8.2 & $27.7 \mathrm{~A}$ \\
\hline UY091 & 41.3 & 39.2 & 19.2 & 6.9 & $26.6 \mathrm{~A}$ \\
\hline UY042 & 38.1 & 38.2 & 17.2 & 7.8 & $25.3 \mathrm{~A}$ \\
\hline UY036 & 35.6 & 38.0 & 18.9 & 7.3 & $24.9 \mathrm{~A}$ \\
\hline UY032 & 40.0 & 34.2 & 14.7 & 6.6 & $23.9 \mathrm{~A}$ \\
\hline UY071 & 18.9 & 20.6 & 1.7 & 0.0 & $10.3 \mathrm{~B}$ \\
\hline UY033 & 16.4 & 16.8 & 0.0 & 0.0 & $8.3 \mathrm{~B}$ \\
\hline UY043 & 9.8 & 11.5 & 0.0 & 0.0 & $5.3 \mathrm{~B}$ \\
\hline Mean $^{z}$ & $32.0 \mathrm{~A}$ & $30.8 \mathrm{~A}$ & $12.4 \mathrm{~B}$ & $4.9 \mathrm{C}$ & $\ldots$ \\
\hline
\end{tabular}

${ }^{\mathrm{w}}$ Two independent experiments were performed, with 13 R. solanacearum strains (experiment 1 ) and a subset of 9 of these strains (experiment 2). Data from both experiments were analyzed separately because of different number of $R$. solanacearum strains evaluated in each trial.

${ }^{\mathrm{x}}$ AUDPC $=$ area under the disease progress curve based on average wilt ratings for each host-strain combination. Refer to the main text for details on the inoculation procedure, rating scale, and data analyses.

y S. tuberosum and S. commersonii plants inoculated with a saline solution (negative control treatments) remained healthy until the end of the experiment.

${ }^{\mathrm{z}}$ Average AUDPC value for each strain and host. Values followed by the same letter in the same column or row within each experiment are not significantly different (Tukey's multiple comparison test, $P=0.05$ ). 
14 days after inoculation (data not shown). Moreover, these strains showed an atypical phenotype in culture, growing as small, round, dark-red colonies on TZC agar medium. Based on these results, we assumed that the archived $R$. solanacearum strains had lost virulence on potato due to long-term storage; therefore, we excluded them from the comparative aggressiveness analysis. Nevertheless, because these isolates were confirmed as $R$. solanacearum by PCR amplification, they were included in the genetic analysis with the strains isolated more recently from affected potato crops in Uruguay.

All Uruguayan strains metabolized disaccharides (lactose, maltose, and cellobiose) but not hexose alcohols (manitol, sorbitol, and dulcitol) (data not shown) and, therefore, were classified as biovar
2 (Table 1). Phylotype-specific multiplex PCR assays resulted in amplification of the expected 281-bp, species-complex-specific fragment as well as a 372-bp amplicon (data not shown), indicating that all strains in the Uruguayan collection belong to phylotype II. All of the Uruguayan strains had identical egl sequences and were assigned to phylotype IIB/sequevar 1 group (IIB1), resembling most strains that cause potato brown rot in temperate regions worldwide (24; Fig. 1; Table 1). This phylogenetic characterization of strains was consistent with the previous designation of the strains as belonging to biovar $2(6)$.

Genomic fingerprinting. A reproducible pattern of amplification products was obtained with the repetitive-sequence (BOX)PCR assays of the $R$. solanacearum strains, with $97 \%$ as the lowest

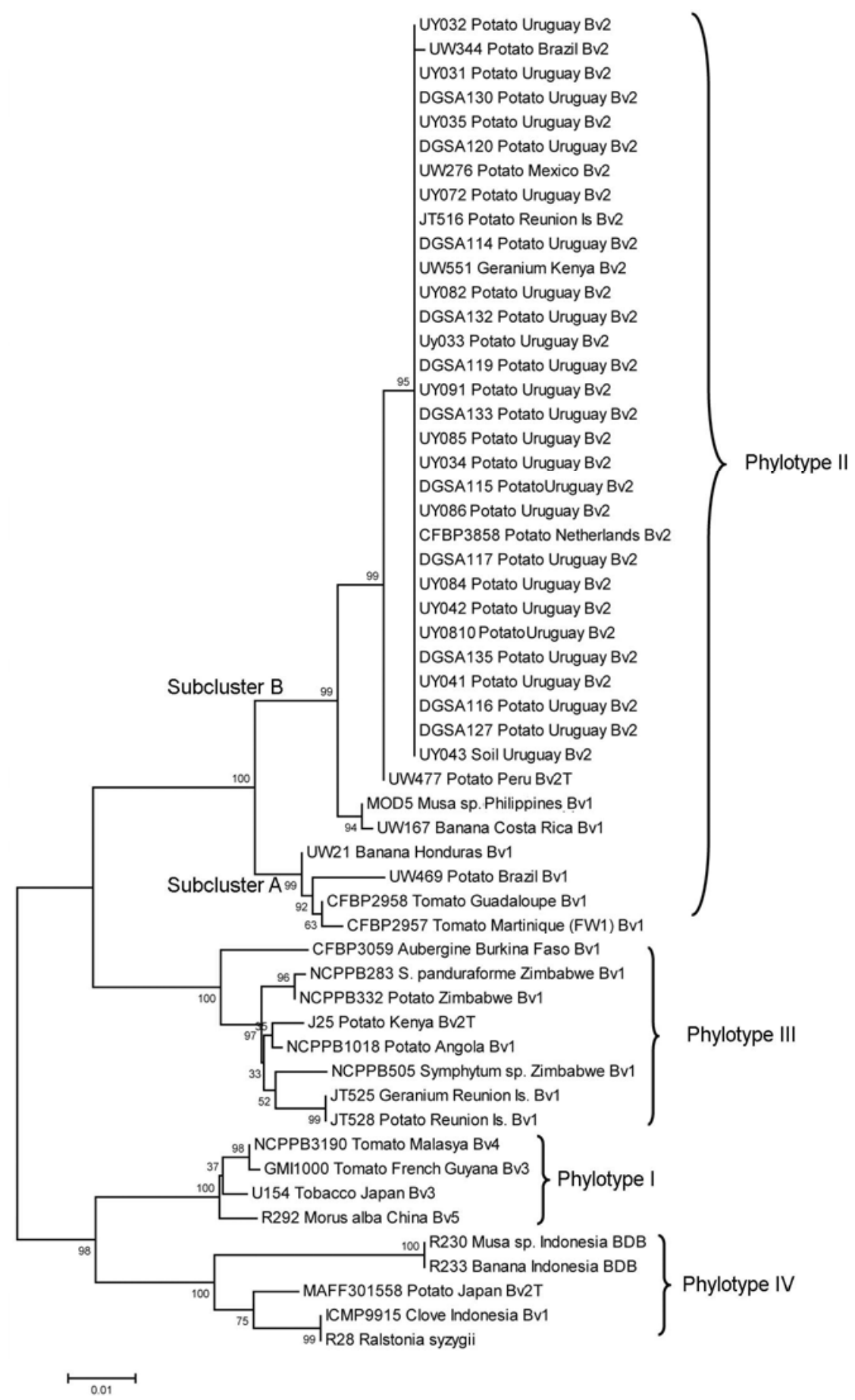

Fig. 1. Phylogenetic neighbor-joining tree based on the partial (690-bp) endoglucanase (egl) gene sequences of 32 Ralstonia solanacearum strains from Uruguay and 28 reference strains from the species complex. Scale bar represents one nucleotide substitution per 100 nucleotides. Refer to the main text for details of egl sequencing and phylogenetic analysis. 
level of reproducibility among replicate assays of the same strain (data not shown). Banding patterns generated by BOX-PCR assay contained 17 to 21 bands ranging from 200 to 3,000 bp (data not shown). In total, 45 discrete, amplified products were scored, of which $8(33.4 \%)$ were polymorphic in at least one pairwise comparison among $R$. solanacearum strains classified as phylotype II, sequevar 1 (data not shown). High similarity was found among genetic profiles of Uruguayan $R$. solanacearum strains and those of reference strains IPO1609 and UW551. Cluster analysis of fingerprint patterns revealed two groups distinguished at a mean similarity of $82 \%$ (Fig. 2). One predominant cluster included reference strains IPO1609 and UW551, all Uruguayan strains isolated from 2003 to 2009, and eight strains isolated in the 1980s. The second cluster included strains DGSA119, DGSA127, and DGSA135 isolated during the 1980s. The average similarity among strains in the first and second clusters was 94 and 100\%, respectively (Fig. 2). Strain GMI1000, an outgroup for the cluster analysis, showed a low level of genetic similarity (45\%) to the remaining strains, thus substantiating the phenetic reliability of the dendrogram, because all $R$. solanacearum strains tested were more closely related to each other than to the outgroup. Moreover, the analysis of cophenetic correlations resulted in a very strong matrix correlation $(r$ $=0.945$ ).

Comparative aggressiveness analysis. In the aggressiveness assays of the $R$. solanacearum strains from Uruguay on tomato and potato using a soil inoculation procedure, the noninoculated con-

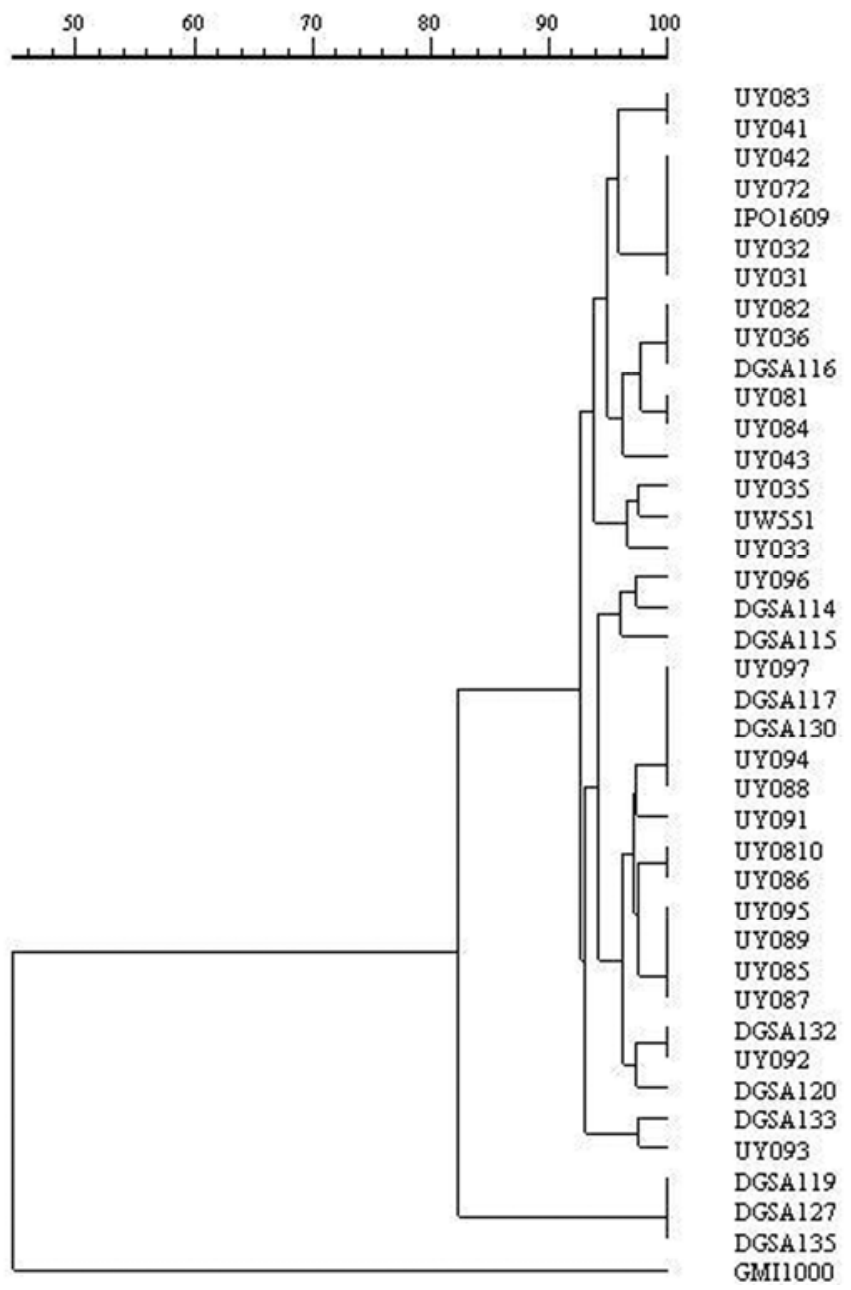

Fig. 2. Dendrogram based on repetitive-sequence polymerase chain reaction (BOX-PCR) fingerprints of 37 Ralstonia solanacearum strains from Uruguay created using unweighted pair-group method using arithmetic averages (UPGMA) clustering of Dice coefficient values (11). Reference strains included in the dendrogram are GMI1000 (outgroup), IP01609, and UW551 (see main text for details of the BOX-PCR assay and UPGMA clustering). trol plants treated with saline solution remained healthy in all repeats of the experiments. Results of the ANOVAs using AUDPC and disease incidence data of tomato and potato assays indicated no significant trial effects, as well as no interactions between trial and treatments (bacterial strains). Therefore, means were pooled across the repeat trials of the same experiment (Table 2). Uruguayan strains were classified in two groups for aggressiveness regardless of the host species on which the strains were assayed $(P$ $<$ 0.0001; Table 2). Strains UY031, UY032, UY034, UY036, UY041, UY042, UY072, UY082, UY084, UY085, UY087, UY089, UY091, and UY092 showed similar high levels of aggressiveness as the reference strain UW551 on both hosts (Table 2). Tomato and potato plants began to develop wilt symptoms 5 to 7 days after inoculation, and more than $80 \%$ of the plants were dead by the end of the experiments. In contrast, strains UY033, UY035, UY043, and UY071 were less aggressive on both tomato and potato. For this group of strains, appearance of symptoms was delayed, beginning 9 to 13 days after inoculation, and the incidence of wilted plants was $<30 \%$ by 21 days after inoculation (Fig. 3). Reference strain IPO1609 grouped with the less aggressive Uruguayan strains on tomato but, statistically, the aggressiveness of this reference strain was not distinguishable from both groups of strains when inoculated on potato. Based on the comparison of mean AUDPC values on tomato or potato, no significant differences in aggressiveness were found among strains isolated in different years from 2003 to 2009 or from different locations (data not shown).

When variation in aggressiveness among a subset of Uruguayan strains was tested on three $S$. commersonii accessions (Table 3 ), the control plants treated with saline solution remained healthy in both experiments. ANOVAs showed highly significant differences among strains of $R$. solanacearum (13 strains tested in the first experiment, and a subset of 9 of these 13 strains tested in the repeat experiment) and among host plants (accessions) $(P<0.0001)$. No significant interaction was observed between the main factors of bacterial strains and host accessions $(P=0.0763$ and 0.7085 for the two experiments; Table 3 ). Therefore, the data were analyzed for each main effect separately. Based on AUDPC ratings, both experiments showed identical results regarding the classification of $R$.

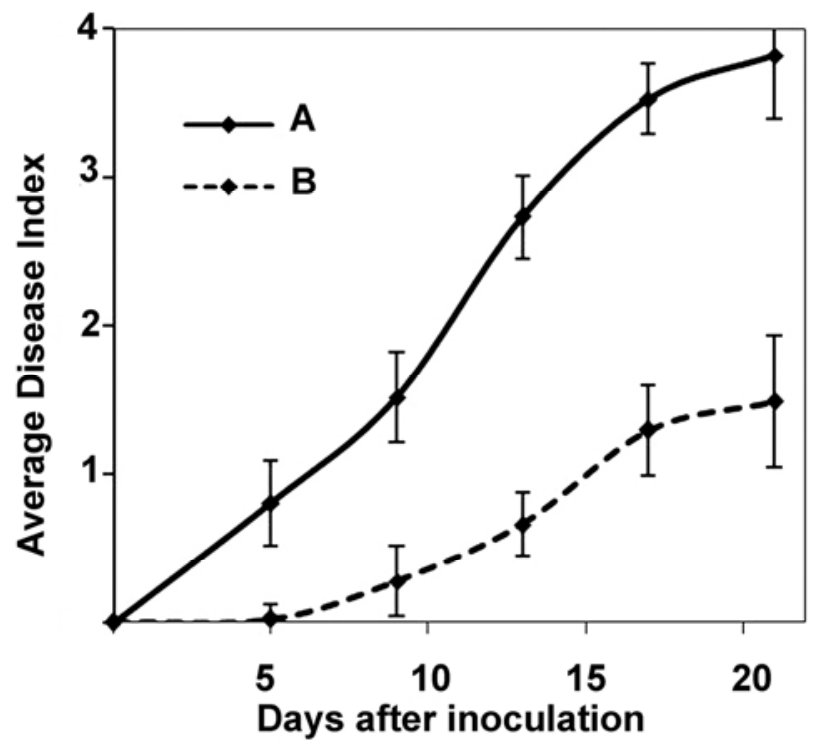

Fig. 3. Development of bacterial wilt on 'Chieftain' potato after soil inoculation with Uruguayan strains of Ralstonia solanacearum with significant differences in aggressiveness on potato (Tukey's multiple comparison test, $P=0.05$ ). Group A includes strains UY031, UY032, UY034, UY036, UY041, UY042, UY082, UY084, UY085, UY087, UY089, UY091, UY092, and reference strain UW551. Group B includes strains UY033, UY035, UY043, and UY071. Each data point represents the mean disease index for two independent experiments. Error bars indicate standard errors of the means. Refer to the main text for details of the soil inoculation procedure, disease severity ratings, and disease index calculations. 
solanacearum strains into two aggressiveness groups. Strains UY031, UY032, UY036, UY041, UY042, UY072, UY082, UY084, UY087, and UY091 were significantly more aggressive than strains UY033, UY043, and UY071. In the latter group, although strain UY043 had the lowest mean AUDPC rating on every host tested in both repeats of the experiment, the mean rating for this strain was not significantly different from those of the other strains in the less-aggressive group.

The three $S$. commersonii accessions evaluated differed significantly in the level of resistance following soil inoculation with Uruguayan strains of $R$. solanacearum in the repeated experiment $(P<0.0001)$. Moreover, both experiments showed the same ranking of S. commersonii accessions based on AUDPC data (Table 3). Accession Sc26 was, statistically, the most susceptible genotype, showing a highly susceptible response to inoculation similar to that of $S$. tuberosum to all the bacterial strains evaluated. Accession Sc1 was, statistically, the most resistant genotype, followed by accession Sc19, which displayed an intermediate response. For the latter two accessions, asymptomatic plants predominated ( $>50 \%)$, and plants that did develop bacterial wilt symptoms showed delayed and less severe symptoms of wilting compared with the susceptible control plants of $S$. tuberosum (data not shown). Bacterial strains classified as more aggressive were able to cause wilting of all three $S$. commersonii accessions, whereas the less-aggressive strains failed to cause symptoms on the most resistant accession, Sc1.

\section{Discussion}

Results of this study showed low genetic diversity among $R$. solanacearum strains affecting potato crops in Uruguay. All strains were classified as biovar 2. In addition, based on the classification system proposed by Fegan and Prior (16), all strains in this Uruguayan collection belonged to phylotype IIB, sequevar 1 (IIB1), historically known as race 3/biovar 2 . This is in agreement with previous reports that IIB1 strains are adapted to mild temperatures $\left(<25^{\circ} \mathrm{C}\right)$ and, therefore, constitute a serious threat to production of susceptible crops in temperate regions of the world (52). R. solanacearum strains belonging to race 1 can affect potato as well as a wide range of other host plants, in contrast to race 3 strains, which have a host range limited to potato and tomato (4). Currently, race 1 strains of $R$. solanacearum are considered quarantine pests in Uruguay (9). Race 1 strains have been reported from southern Brazil (45), meaning there is a risk of introducing strains of that race through bordering areas where exchange of plant material is hard to control. Therefore, control of potato and plant material movement at borders should be enforced, and a more extensive survey, including other susceptible hosts, should be implemented in Uruguay.

In this study, we included a set of $R$. solanacearum strains isolated in Uruguay in the 1980s and maintained in the Plant Protection Service collection in Uruguay. These archival strains were nonpathogenic on potato following direct stem inoculations; therefore, they were not included in the comparative aggressiveness analysis. This was supported by the phenotype of these strains observed on TZC agar medium, which resembled phenotypic conversion mutant strains previously described in $R$. solanacearum (30). Spontaneous phenotypic conversion mutants are generated under stressful conditions and are often observed during long-term storage or repetitive subculturing of the pathogen. When this phenomenon occurs, the wild-type strain loses pathogenicity in association with multiple changes, including colony morphology, motility, and production of virulence factors $(20,30,42)$. It has been established that susceptible crops can specifically induce reversion of phenotypically converted strains back to the wild-type (39). However, we did not reisolate the bacterium from asymptomatic plants 14 days after inoculation with these 1980s strains. Regardless of the phenotype of these strains, the strains were subjected to molecular characterization, revealing that they all belonged to phylotype IIB, sequevar 1 . These results concur with the previous assignation of the strains to race 3, biovar 2 (6).

DNA fingerprint analyses based on rep-PCR assays have been widely used to assess diversity and genetic relationships among $R$. solanacearum strains $(26,28,33,47,51)$. In this study, we applied BOX-PCR assays to analyze genetic variation among $R$. solanacearum strains isolated from potato fields in Uruguay. PCRbased techniques are usually subject to variations that reflect many factors, such as template and primer DNA concentrations and composition of the PCR buffer. Therefore, we compared the band patterns between replicate assays of the same strains and found a high level of reproducibility (97\%). High similarity was also found among genetic profiles of Uruguayan $R$. solanacearum strains, suggesting that a single clonal population might be involved in outbreaks of bacterial wilt in all potato-growing areas of Uruguay. This is consistent with previous reports in which IIB1 strains of $R$. solanacearum have shown high genetic homogeneity, possibly reflecting the adaptation of this phylotype to low temperatures and the relatively narrow host range $(40,49,51)$. Despite the low genetic variability detected, clustering analysis of DNA fingerprints patterns revealed two distinct groups of Uruguayan strains. The predominant cluster contained most of the Uruguayan strains as well as reference strains IPO1609 and UW551. Eight of the 1980s archival strains collected from potato crops had fingerprints with a mean level of similarity of $94 \%$ compared with those of strains collected in 2003 to 2009, suggesting the prevalence of the same genetic lineage as in the 1980s. On the other hand, three strains isolated during the 1980s in the same location (San José) formed a separate group with $84 \%$ similarity to the other genetic cluster that included all the other Uruguayan strains. This distinct genotype was not represented in the strains collected from 2003 to 2009. Further research using additional molecular tools could test this hypothesis and be used to analyze genetic differences between both groups of strains.

In contrast to the low level of genetic diversity observed, variation in aggressiveness among Uruguayan $R$. solanacearum strains isolated during the period 2003 to 2009 was detected on several hosts following the soil inoculation protocol. Aggressiveness characterization was performed on tomato and potato because these are the main susceptible crops grown in Uruguay. Most Uruguayan strains showed aggressiveness on these two hosts similar to that of reference strain UW551, which was highly aggressive on tomato and potato. In contrast, some strains exhibited low aggressiveness, typically in the form of delayed appearance of symptoms and significantly more nonwilted plants at the end of the experiments. These strains were consistently less aggressive on both hosts when the experiments were repeated. Several other studies have reported differences in aggressiveness among $R$. solanacearum strains belonging to other biovars or when comparing different biovars and races $(18,28,34)$. To our knowledge, this is the first report of different aggressiveness levels among $R$. solanacearum strains belonging to IIB1.

No significant differences in aggressiveness were found among groups of strains with different geographic origins. Because only two of the strains were isolated from soil samples in this study (UY043 and UY071), no conclusions can be made regarding the nature of the samples used (soil or tuber) for isolation of $R$. solanacearum. Recently, the first genotypic and phenotypic characterization of a set of $R$. solanacearum biovar 2 strains obtained from Dutch local waterways as well as asymptomatic bittersweet $(S$. dulcamara) plants was reported (49). In that study, no significant differences in pathogenicity were found between these strains compared with reference $R$. solanacearum strains isolated from symptomatic potato plants. However, this evaluation was limited to tomato and done with few strains (15 strains from water samples or bittersweet plants and 2 reference strains isolated from potato) (49).

Although some studies have reported the use of $S$. commersonii as a source of resistance to bacterial wilt $(7,32)$, little is known about resistance properties across the spectrum of diversity in this wild species. In the present study, three $S$. commersonii genotypes were selected from a previous screening (46) and tested for resistance to a subset of $R$. solanacearum strains from Uruguay. No significant interaction was found between pathogen strains and host genotypes, because all strains were ranked in the same order 
regardless of the $S$. commersonii accession tested. However, differences in aggressiveness among the $R$. solanacearum strains were observed, and were consistent with the aggressiveness ratings on tomato and potato. This suggests that the low aggressiveness observed for some strains is not host specific. Moreover, the results indicate that germplasm selection with highly aggressive strains may be a promising strategy for breeding programs in Uruguay.

Significant differences in resistance to $R$. solanacearum were observed among the three $S$. commersonii accessions evaluated. The accessions were selected to represent different levels of bacterial wilt resistance based on a previous screening of a germplasm collection of $S$. commersonii accessions from Uruguay (46). However, the latter screening was performed with a single $R$. solanacearum strain (UY031) using a stem inoculation protocol (46). In the present study, we evaluated the three $S$. commersonii accessions against $13 R$. solanacearum strains using a soil inoculation procedure, which more accurately resembles the natural method of infection of plants by $R$. solanacearum than stem inoculation. A similar resistance response of the $S$. commersonii accessions was observed with soil inoculation compared with the previous stem inoculation method. This may indicate that resistance in $S$. commersonii is associated with the ability of the plant to restrict bacterial invasion and multiplication inside plant tissues. Unfortunately, little is known about the plant-pathogen interactions for bacterial wilt of potato. Studies on tomato suggest that activation of secondary metabolism of phenolic compounds and xylem cell wall structure appear to contribute to reduced bacterial multiplication in the plant $(53,55)$. Further research comparing the root infection process of $S$. commersonii accessions with different levels of resistance to $R$. solanacearum is needed to test this hypothesis.

Accession Sc1 of $S$. commersonii was consistently the most resistant of the three accessions evaluated, showing mild symptoms even when challenged with aggressive strains of $R$. solanacearum. Therefore, this accession has been selected as a progenitor for a potato breeding program in Uruguay. Another important aspect to consider is the ability of $R$. solanacearum strains to cause latent infections in resistant plants. Plants of such resistant genotypes may not show symptoms but the roots or stems may be infected by the bacterium (23). Because latently infected plant material may constitute a source of inoculum, potentially leading to outbreaks of the disease, screening for resistance to latent infection by $R$. solanacearum has been recommended for potato breeding (41). In this study, assessment of bacterial populations in asymptomatic plants was not performed, and genotypes were classified as resistant based solely on the absence of disease symptoms.

The variation in responses observed for three $S$. commersonii accessions to inoculation with $R$. solanacearum highlights the potential of this wild species as a source of resistance for potato breeding. Studies are now underway to investigate the genetic basis of this resistance, through the development of a segregating population from crossing different $S$. commersonii accessions. Preliminary characterization of bacterial wilt resistance in these target populations has revealed segregation of this resistance, suggesting that resistance in $S$. commersonii is determined by a few independent genes with additive effects (M. González, personal communication).

In conclusion, this study confirmed that potato crops with symptoms of bacterial wilt that were surveyed in Uruguay were all infected by $R$. solanacearum strains belonging to phylotype IIB, sequevar 1 . Despite the low level of genetic diversity among the Uruguayan $R$. solanacearum strains, based on BOX-PCR analysis, variation in aggressiveness was detected on three host plant species, revealing (for the first time) different aggressiveness levels among IIB1 strains of $R$. solanacearum. This study also highlights the potential of $S$. commersonii as a valuable source of resistance for potato breeding. This wild species harbors genetic and phenotypic diversity and is well adapted to environmental conditions in Uruguay. Results of this study confirmed different levels of resistance within this wild species, and pave the way to identifying more resistant genotypes for breeding. Such resistance will con- tribute to an integrated approach to control bacterial wilt of potato in Uruguay.

\section{Acknowledgments}

This work was supported by grants PDT 54/190 and CSIC 273, and a Ph.D. scholarship provided to M. I. Siri by the Basics Sciences Development Program from (PEDECIBA) and the National Agency for Innovation and Research in Uruguay (ANII). We thank N. Schaad, C. Boucher, and G. Galván for critical review of the manuscript; A. Castillo for technical advice and logistical support with in vitro plant propagation; E. Verdier for providing archival $R$. solanacearum strains from the collection of the governmental Plant Protection Service in Uruguay; and L. Gutierrez for help with aggressiveness data analysis.

\section{Literature Cited}

1. Ausubel, F. H., Brent, R., Kingston, R. E., Moore, D. D., Seidman, J. G., Smith, J. A., and Struth, K. 1994. Current Protocols in Molecular Biology. John Wiley \& Sons, Chichester, Canada.

2. Boshou, L. 2005. A broad review and perspective on breeding for resistance to bacterial wilt. Pages 225-238 in: Bacterial Wilt: The Disease and the Ralstonia solanacearum Species Complex. C. Allen, P. Prior, and A. C. Hayward, eds. American Phytopathological Society, St. Paul, MN.

3. Bradshaw, J. E., Bryan, G. J., and Ramsay, G. 2006. Genetic resources (including wild and cultivated Solanum species) and progress in their utilisation in potato breeding. Potato Res. 49:49-65.

4. Buddenhagen, I., Sequeira, L., and Kelman, A. 1962. Designation of races in Pseudomonas solanacearum. (Abstr.) Phytopathology 52:726.

5. Canale, F. 1984. Situación de Pseudomonas solanacearum en la República Oriental del Uruguay. Pages 27-33 in: Seminario de Investigación y de Trabajo Sobre Avances en el Control de la Marchitez Bacteriana (Pseudomonas solanacearum) de la Papa en América Latina, CIP, Lima, Perú.

6. Canale, F., and Peralta, A. 1983. Determinación de biotipos de Pseudomonas solanacearum en aislamientos procedentes de la zona sur de San José. Rev. AIA 1:90-93.

7. Carputo, D., Aversano, R., Barone, A., Di Matteo, A., Iorizzo, M. Sigillo, L., Zoina, A., and Frusciante, L. 2009. Resistance to Ralstonia solanacea rum of sexual hybrids between Solanum commersonii and S. tuberosum. Am. J. Potato Res. 86:196-202.

8. Carputo, D., Castaldi, L., Caruso, I., Aversano, R., Monti, L., and Frusciante, L. 2007. Resistance to frost and tuber soft rot in near-pentaploid Solanum tuberosum-S. commersonii hybrids. Breed. Sci. 57:145-151.

9. De Hegedüs, P. Lista de plagas cuarentenarias ausentes en Uruguay. Ministerio de Ganadería Agricultura y Pesca, Dirección General de Servicios Agrícolas. https://www.ippc.int/index.pxp?id=nppoury

10. Denny, T. P. 2006. Plant pathogenic Ralstonia species. Pages 573-644 in: Plant Associated Bacteria. S. S. Gnanamanickam, ed. Springer Publishing, Dordrecht, The Netherlands.

11. Dice, L. R. 1945. Measures of the amount of ecologic association between species. Ecology 26:297-302.

12. Dirección de Estadísticas Agropecuarias (DIEA). Caracterización de la Producción de Papa. Estadísticas Agropecuarias, Ministerio de Ganadería Agricultura y Pesca. http://www.mgap.gub.uy/portal/hgxpp001.aspx?7,5, 111,O,S,0,MNU;E;42;7;MNU

13. Di Rienzo, J. A., Casanoves, F., Balzarini, M. G., Gonzalez, L., Tablada, M., and Robledo, C. W. InfoStat Versión 2009. Grupo InfoStat, FCA, Universidad Nacional de Córdoba, Argentina.

14. Elphinstone, J. G. 2005. The current bacterial wilt situation: a global overview. Pages 9-28 in: Bacterial Wilt: The Disease and the Ralstonia solanacearum Species Complex. C. Allen, P. Prior, and A. C. Hayward, eds. American Phytopathological Society, St. Paul, MN.

15. Elphinstone, J. G., Hennessey, J., Wilson, J. K., and Stead, D.E. 1996 Sensitivity of different methods for the detection of Ralstonia solanacearum in potato tuber extracts. EPPO Bull. 26:663-678.

16. Fegan, M., and Prior, P. 2005. How complex is the 'Ralstonia solanacearum' species complex? Pages 449-461 in: Bacterial Wilt: The Disease and the Ralstonia solanacearum Species Complex. C. Allen, P. Prior, and A. C. Hayward, eds. American Phytopathological Society, St. Paul, MN.

17. Fegan, M., Taghavi, M., Sly, L. I., and Hayward, A. C. 1998. Phylogeny, diversity and molecular diagnostics of Ralstonia solanacearum. Pages 1933 in: Bacterial Wilt Disease: Molecular and Ecological Aspects. P. Prior, C. Allen, and J. Elphinstone, eds. Springer-Verlag, New York.

18. Fock, I., Luisetti, J., Collonier, C., Vedel, F., Ducreux, G., Kodja, H., and Sihachakr, D. 2005. Solanum phureja and S. stentotum are sources of resistance to Ralstonia solanacearum for somatic hybrids of potato. Pages 253 259 in: Bacterial Wilt: The Disease and the Ralstonia solanacearum Species Complex. C. Allen, P. Prior, and A. C. Hayward, eds. American Phytopathological Society, St. Paul, MN

19. French, E. R., Anguiz, R., and Aley, F. P. 1998. The usefulness of potato resistance to Ralstonia solanacearum for the integrated control of bacterial wilt. Pages 381-385 in: Bacterial Wilt disease: Molecular and Ecological Aspects. P. Prior, C. Allen, and J. Elphinstone, eds. Springer-Verlag, New York.

20. Genin, S., Brito, B., Denny, T. P., and Boucher, C. 2005. Control of the Ralstonia solanacearum type III secretion system (Hrp) genes by the global 
virulence regulator PhcA. FEBS Lett. 579:2077-2081.

21. Hawkes, J. G. 1990. The Potato: Evolution, Diversity and Genetic Resources. Belhaven Press, London.

22. Hayward, A. C. 1964. Characteristics of Pseudomonas solanacearum. J. Appl. Bacteriol. 27:265-277.

23. Hayward, A. C. 1991. Biology and epidemiology of bacterial wilt caused by Pseudomonas solanacearum. Annu. Rev. Phytopathol. 29:65-87.

24. Hayward, A. C. 1994. The hosts of Pseudomonas solanacearum. Pages 923 in: Bacterial Wilt: The Disease and its Causative Agent, Pseudomonas solanacearum. A. C. Hayward and G. L. Hartman, eds. CAB International, Wallingford, UK

25. Hendrick, C., and Sequeira, L. 1984. Lipopolysaccharide-defective mutants of the wilt pathogen Pseudomonas solanacearum. Appl. Environ. Microbiol. 48:94-101.

26. Horita, M., Suga, Y., Ooshiro, A., and Tsuchiya, K. 2010. Analysis of genetic and biological characters of Japanese potato strains of Ralstonia solanacearum. J. Gen. Plant Pathol. 76:196-207.

27. Instituto Nacional de Semillas (INASE). Estándares específicos para la producción de materiales de propagación de papa (Solanum tuberosum) de la clase certificada. http://www.inase.org.uy/especiesCultivares/Estandares Especificos.aspx

28. Jaunet, T. X., and Wang, J. F. 1999. Variation in genotype and aggressiveness diversity of Ralstonia solanacearum race 1 isolated from tomato in Taiwan. Phytopathology 9:320-327.

29. Jukes, T. H., and Cantor, C. R. 1969. Evolution of protein molecules. Pages 121-132 in: Mammalian Protein Metabolism. H. N. Munro, ed. Academic Press, New York.

30. Kelman, A., 1954. The relationship of pathogenicity in Pseudomonas solanacearum to colony appearance on a tetrazolium medium. Phytopathology 44:693-695.

31. Kumar, S., Tamura, K., and Nei, M. 2004. MEGA3: integrated software for molecular evolutionary genetics analysis and sequence alignment. Brief. Bioinf. 5:150-163.

32. Laferriere, L. T., Helgeson, J. P., and Allen C. 1999. Fertile S. tuberosum + $S$. commersonii somatic hybrids as sources of resistance to bacterial wilt caused by $R$. solanacearum. Theor. Appl. Genet. 98:1272-1278.

33. Lewis Ivey, M. L., McSpadden Gardener, B. B., Opina, N., and Miller, S.A. 2007. Diversity of Ralstonia solanacearum infecting eggplant in the Philippines. Phytopathology 97:1467-1475.

34. Lopes, C. A., Carvalho, S. I. C., and Boiteux, L. S. 2005. Search for resistance to bacterial wilt in a Brazilian Capsicum germplasm collection. Pages 247-251 in: Bacterial Wilt: The Disease and the Ralstonia solanacearum Species Complex. C. Allen, P. Prior, and A. C. Hayward, eds. American Phytopathological Society, St. Paul, MN.

35. Louws, F. J., Fulbright, D. W., and de Bruijn, F. J. 1994. Specific genomic fingerprints of phytopathogenic Xanthomonas and Pseudomonas pathovars and strains generated with repetitive sequences and PCR. Appl. Environ. Microbiol. 60:2286-2295.

36. Montanelli, C., Chiari, A., Chiari, T., Stefanini, F., and Nascari, G. 1995. Evaluation of resistance to Pseudomonas solanacearum in potato under controlled conditions. Euphytica 81:35-43.

37. Montgometry, D. C. 2005. Diseño y Análisis de Experimentos. Editorial Limusa, México, D.F., México.

38. Murashige, T., and Skoog, F. 1962. A revised medium for rapid growth and bioassays with tobacco tissue culture. Physiol. Plant. 15:473-497.

39. Poussier, S., Trigalet-Demery, D., Barthet, S., Thoquet, P., Arlat, M., and Trigalet, A. 2005. Phase reversion from phenotype conversion mutants to wild type may be induced in Ralstonia solanacearum by a susceptible host plant. Pages 351-357 in: Bacterial Wilt: The Disease and the Ralstonia solanacearum Species Complex. C. Allen, P. Prior, and A. C. Hayward, eds.
American Phytopathological Society, St. Paul, MN.

40. Poussier, S., Trigalet-Demery, D., Vandewalle, P., Goffinet, B., Luisetti, J., and Trigalet, A. 2000. Genetic diversity of Ralstonia solanacearum as assessed by PCR-RFLP of the hrp gene region, AFLP and 16S rRNA sequence analysis, and identification of an African subdivision. Microbiology 146:1679-1692.

41. Priou, S., Salas, C., De Mendiburu, F., Aley, P., and Gutarra, L. 2001. Assessment of latent infection frequency in progeny tubers of advanced potato clones resistant to bacterial wilt: a new selection criterion. Potato Res. 44:359-373.

42. Schell, M. A. 2000. Control of virulence and pathogenicity genes of Ralstonia solanacearum by an elaborate sensory array. Annu. Rev. Phytopathol. 38:263-292.

43. Seal, S. E., Jackson, L. A., Young, J. P. W., and Daniels, M. J. 1993. Differentiation of Pseudomonas solanacearum, Pseudomonas syzygii, Pseudomonas picketti and the Blood Disease Bacterium by partial $16 \mathrm{~S}$ rRNA sequencing: construction of oligonucleotide primers for sensitive detection by polymerase chain reaction. J. Gen. Microbiol. 139:1587-1594.

44. Silveira, E. B., Gomes, A. M. A., Michereff, S. J., and Mariano, R. L. R 1998. Variability of Ralstonia solanacearum populations causing wilt on tomato in Agreste of Pernambuco, Brazil. Bacterial Wilt Newsl. 15:8-10.

45. Silveira, J. R. P., Duarte, V., and Moraes, M. G. 2002. Ocorrência das biovares 1 e 2 de Ralstonia solanacearum em lavouras de batata no Estado do Rio Grande do Sul. Fitopatol. Bras. 27:450-453.

46. Siri, M. I., Galván, G., Quirici, L., Silvera, E., Villanueva, P., Ferreira, F., Franco-Fraguas, L., and Pianzzola, M. J. 2009. Molecular marker diversity and bacterial wilt resistance in wild Solanum commersonii accessions from Uruguay. Euphytica 165:371-382.

47. Smith, J. J., Offord, L. C., Holderness, M., and Saddler, G. S. 1995. Genetic diversity of Burkholderia solanacearum (synonym Pseudomonas solanacearum) race 3 in Kenya. Appl. Environ. Microbiol. 61:4263-4268.

48. Sokal, R. R., and Rohlf, F. J. 1962. The comparison of dendrograms by objective methods. Taxon 11:30-40.

49. Stevens, P., and Van Elsas, J. D. 2009. Genetic and phenotypic diversity of Ralstonia solanacearum biovar 2 strains obtained from Dutch waterways. Antonie Leeuwenhoek 97:171-188.

50. Tozzini, A. C., Cerioani, M. F., Saladrigas, M. V., and Hopp, H. E. 1991. Extreme resistance to infection by potato virus in genotypes of wild tuberbearing Solanum species. Potato Res. 34:317-324.

51. Van der Wolf, J. M., Bonants, P. J. M., Smith, J. J., Hagenaar M., Nijhuis, E., van Beckhoven, J. R. C. M., Saddler, G. S., Trigalet, A., and Feuillade, R. 1998. Genetic diversity of Ralstonia solancaerum Race 3 in Western Europe determined by AFLP, RC-PFGE and Rep-PCR. Pages 44-49 in: Bacterial Wilt Disease: Molecular and Ecological Aspects. P. Prior, C. Allen, and J. Elphinstone, eds. Springer-Verlag, New York.

52. Van Elsas, J. D., Kastelein, J., van Bekkum, P., van der Wolf, J. M., de Vries, P. M., and van Overbeek, L. S. 2000. Survival of Ralstonia solanacearum biovar 2 , the causative agent of potato brown rot, in field and microcosm soils in temperate climates. Phytopathology 90:1358-1366.

53. Vasse, J., Danoun, S., and Trigalet, A. 2005. Microscopic studies of root infection in resistant tomato cultivar Hawaii 7996. Pages 285-291 in: Bacterial Wilt: The Disease and the Ralstonia solanacearum Species Complex. C. Allen, P. Prior, and A. C. Hayward, eds. American Phytopathological Society, St. Paul, MN

54. Winstead, N. N., and Kelman, A. 1952. Inoculation techniques for evaluating resistance to Pseudomonas solanacearum. Phytopathology 42:628-634.

55. Wydra, K., and Ber, H. 2007. Immunohistochemical changes in methyl-ester distribution of homogalacturonan and side chain composition of rhamnogalacturonan I as possible components of basal resistance in tomato inoculated with Ralstonia solanacearum. Physiol. Mol. Plant Pathol. 70:13-24. 